\title{
Profil Industri Rumah Tangga Rakik di Kecamatan Pauh Kota Padang
}

\author{
Variyetmi Wira \\ Jurusan Administrasi Niaga, Politeknik Negeri Padang \\ Gustati \\ Jurusan Akuntansi, Politeknik Negeri Padang
}

\begin{abstract}
West Sumatra is famous for various types of cuisine that contain a lot of spices, marinades and have good taste. This can be either culinary or cooking traditional cakes. One of the traditional cakes are brittle or known by Rakik. These efforts form of home industry. This study is a survey of two industry tanggga rakik house in the district of Padang Pauh, which had stood for 20 years, namely Mrs. Fatmawati Rakik Enterprises and Enterprises Rakik Mother Yulidar. Various problems faced by the domestic industry of which this is still traditional activities, lack of good financial management, packaging products and trademarks are less attractive, and yet the drafting of financial statements in accordance with standards (SAK-ETAP).
\end{abstract}

Keyword : rakik, kue tradisional, pengelolaan keuangan, pengemasan produk, laporan keuangan.

\section{Latar Belakang masalah}

Usaha Mikro, Kecil, dan Menengah (UMKM) memiliki peran penting dalam perekonomian Indonesia. Adanya UMKM pengangguran akibat angkatan kerja yang tidak terserap dalam dunia kerja menjadi berkurang. Karena itu, upaya pemberdayaan koperasi dan UMKM akan berdampak pada perluasan lapangan kerja, dan roda perekonomian di pedesaan maupun perkotaan, terutama di kalangan masyarakat miskin. Pemberdayaan

tersebar di pedesaan dan perkotaan. Data BPS Sumatera Barat tahun 2006, mencatat sebanyak 501.410 UMKM. Rata rata peningkatan jumlah UMKM di Indonesia pada lima tahun terakhir adalah 2,43\%, sehingga diprediksi jumlah UMKM di Sumatera Barat pada tahun 2013 ada sebanyak 593.175 unit (Data Dinas Koperasi, Usaha Mikro Kecil dan Menengah Sumatera Barat, 2013).

Permasalahan utama yang dihadapi oleh UMKM adalah rendahnya produktivitas dari UMKM dan terbatasnya akses ke sumber daya produktif terutama permodalan, teknologi, informasi dan pasar. Dalam hal permodalan, pelaku UMKM mayoritas menggunakan modal sendiri dalam menjalankan usaha. Jika UMKM membutuhkan dana tambahan, maka dana dapat diperoleh dari lembaga keuangan mikro usaha mikro, kecil, dan menengah (UMKM) serta koperasi menjadi pilihan strategi untuk meningkatkan taraf hidup sebagian besar rakyat Indonesia.

Di Indonesia jumlah populasi UMKM mencapai 48,9 juta unit usaha atau $99,9 \%$ dari jumlah unit usaha di Indonesia. Sedangkan di Sumatera Barat, data jumlah UMKM yang ada di Sumatera Barat sulit diperoleh, karena sebagian besar UMKM tidak berbadan hukum (sektor informal) dan dimiliki perorangan yang dan koperasi. Sehingga kedua lembaga ini sangat mempengaruhi perkembangan UMKM.

Sumatera Barat terkenal dengan berbagai jenis kuliner yang mengandung banyak rempah, bumbu-bumbu dan mempunyai citarasa tinggi. Kuliner ini dapat berupa masakan ataupun kue-kue tradisional. Salah satu kue tradisional tersebut adalah Rempeyek atau dikenal dengan Rakik. Usaha ini berbentuk home industry yang aktifitasnya masih bersifat tradisional dan manajemen yang tidak profesional, dan belum melakukan penyusunan laporan keuangan. Pada berbagai penelitian, UMKM belum menyusun dan catatan laporan keuangan yang tertata dengan baik.

Masalah keuangan sering kali menjadi 
salah satu masalah besar dan merupakan mayoritas dialami Usaha Mikro Kecil Menengah (UMKM). Dalam menjalankan usahanya, pelaku UMKM tidak hanya dihadapkan pada masalah cara memperoleh uang masuk, tapi juga persoalan kemampuan mengelola dan mengendalikan keuangan entitas. Mayoritas pelaku UMKM merasa omset yang diperoleh sudah cukup besar, namun pada kenyataannya mereka tidak memperoleh keuntungan dari usahanya tersebut. Hal ini disebabkan pelaku UMKM belum bisa mengelola keuangan dengan baik, sehingga usaha mereka meskipun sudah berjalan lama namun tidak dapat tumbuh kembang.

\subsection{Rumusan Masalah}

Dari uraian diatas dapat dibuat suatu rumusan masalah yaitu bagaimana profil UMKM khususnya industri rumah tangga rakik di Kecamatan Pauh, Padang, Sumatera Barat, khususnya pada Usaha Rakik Julidar dan Usaha Rakik Fatmawati?

\section{Literatur}

\subsection{Pengertian Usaha Mikro.}

Industri di Indonesia dapat digolongkan kedalam beberapa macam kelompok. Industri didasarkan pada banyaknya tenaga kerja dibedakan menjadi 4 golongan,yaitu: 1).Industri besar, memiliki jumlah tenaga kerja 100 orang atau lebih; 2). Industri sedang, memiliki jumlah tenaga kerja antara 20-99 orang, 3). Industri kecil, memiliki jumlah tenaga kerja antara 5-19 Modul Manajemen Usaha Kecil menuliskan bahwa salah satu bahasan penting dalam topik Bauran Pemasaran adalah kemasan dan label produk.

2.2.1 Kemasan. Pengemasan merupakan kegiatan untuk merancang dan memperoleh wadah dan pembungkus untuk suatu produk, kemasan tidak hanya digunakan untuk pelindung terhadap produk tetapi juga digunakan untuk meningkatkan citra produk. Oleh karena itu syarat kemasan adalah a).Harus dapat melindungi produk terhadap kerusakan, kebocoran dan kehilangan; b).Harus praktis dan ekonomis sehingga memudahkan konsumen baik membawanya orang, 4). Industri rumah tangga, memiliki jumlah tenaga kerja antara 1-4 orang (BPS, 2002).

Menurut Peraturan Direksi Lembaga Pengelola Dana Bergulir Koperasi dan Usaha Mikro, Kecil, dan Menengah Nomor : 36/PER/LPDB/2010 tentang Petunjuk Teknis Pemberian pinjaman/pembiayaan kepada koperasi, Usaha Mikro adalah usaha produktif milik orang perorangan dan/atau badan usaha perorangan yang memenuhi kriteria a).Memiliki kekayaan bersih paling banyak Rp.50.000.000,- (lima puluh juta rupiah) tidak termasuk tanah dan bangunan tempat usaha; atau b). Memiliki hasil penjualan tahunan paling banyak Rp.300.000.000,- (tiga ratus juta rupiah).

Menurut Kemendiknas (2010) dalam Modul tentang Manajemen Usaha Kecil disebutkan bahwa usaha kecil memiliki ciri-ciri (1).Manajemen tergantung pemilik; (2).Modal disediakan oleh pemilik sendiri; (3).Skala usaha dan jumlah modal relatif kecil; (4).Daerah operasi usaha bersifat lokal; (5).Sumber daya manusia yang terlibat terbatas; (6).Biasanya berhubungan dengan kebutuhan kehidupan sehari-hari; (7).Karyawan ada hubungan kekerabatan emosional; dan (8).Mayoritas karyawan berasal dari kalangan yang tidak mampu secara ekonomis.

\subsection{Kemasan dan Label.}

Dalam Kemendiknas (2010) dalam

maupun penyimpanannnya; c).Ukurann kemasan harus sesuai dengan kehendak konsumen; d).Kemasan hendaknya memberikan aspek deskriptif yaitu: menggambarkan merk, kualitas, rasa, campuran atau kombinasi di antaranya; e).Mempunyai citra dan aspek tertentu,misalnya kemasannya untuk keperluan kecantikan biasanya kemasannya sangat menarik, sehingga memberi kesan barang yang mahal.

2.2.2 Label, adalah bagian dari kemasan dan merupakan informasi tercetak yang terlekat pada kemasan yang memuat tentang produk. Fungsi label adalah sebagai berikut: 
a).Mengidentifikasi produk/merk; b). Menjelaskan tingkat mutu; c).Menerangkan tentang produk, yaitu (1). siapa yang membuatnya, (2). di mana dibuat, (3). kapan dibuat, (4). apa isinya, (5). cara menggunakannya; d).Mempromosikan produk melalui grafirannya yang menarik.

\subsection{Pengelolaan Keuangan UMKM}

Salah satu permasalahan krusial yang dihadapi usaha kecil adalah pengelolaan keuangan karena pada umumnya pengelolaan keuangan usaha kecil belum teradministrasi dengan baik dimana pengelolaan keuangan belum dipisahkan antara keperluan usaha dan keperluan pribadi (rumah tangga). Hal tersebut dapat berakibat pada kelangsungan usaha ke depannya karena pemilik usaha tidak bisa mengetahui secara pasti keuntungan yang diperoleh perbulannya dari usaha yang dijalankannya sehingga perencanaan usaha/planning secara pasti tidak dapat dibuat. Permasalahan tersebut membawa dampak bagi kemajuan dan perkembangan usaha kecil, untuk itu diperlukan adanya pengetahuan dan ketrampilan mengenai akuntansi dan pengelolaan keuangan. Makalah ini memberikan gambaran umum mengenai pengetahuan akuntansi dan bagaimana mengelola keuangan secara baik (Rahmawati, 2008)

Menurut Tyningdiah (2013) bahwa manajemen keuangan bukan sekedar bagaimana memanajemen uang kas. Tapi lebih dari itu, manajemen keuangan adalah bagaimana anda mengelola kekayaan untuk menghasilkan keuntungan dan memanfaatkan sumber-sumber modal untuk membiayai usaha. Meski sederhana, pengusaha kecil dan menengah pun perlu menerapkan prinsip-prinsip manajemen keuangan.

Berikut beberapa dasar manajemen keuangan bagi UKM menurut Tyningdiah (2013) : (1). Pisahkan uang pribadi dan usaha; (2). Rencanakan penggunaan uang; (3).Buat buku catatan keuangan; (4). Hitung keuntungan dengan benar; (5). Putar arus kas lebih cepat; (6). Awasi harta, hutang dan modal; (7). Sisihkan keuntungan untuk pengembangan usaha.

\subsection{Pembukuan sederhana usaha kecil dan rumahan}

Aditya Fajar (2013) menuliskan bahwa pembukuan sederhana usaha bisa diawali dari pencatatan arus kas. Karena dalam operasinya, keuangan usaha kecil dan rumahan umumnya masih terfokus pada aliran uang tunai. Namun perlu diingat bahwa pembukuan sederhana ini hanyalah bagian kecil dari praktek akuntansi yang sebenarnya, yaitu pencatatan aliran uang kas. Tapi karena usaha kecil dan rumahan umumnya masih terfokus pada transaksi tunai (cash/bank transfer), maka pembukuan usaha bisa dimulai dari sini dulu. Pos-pos dalam pembukuan yang diperlukan adalah Kasir, Belanja, dan Penjualan.

Pos Kasir adalah pos keuangan utama di mana seluruh uang terpusat. Kalau diibaratkan pangkalan taksi, maka Pos Kasir adalah poolnya. Pos Kasir juga merupakan pos yang mendistribusikan uang ke Pos Belanja. Sementara itu Pos Penjualan adalah pos yang mencatat seluruh penjualan produk yang kita punya. Uang hasil penjualan dikumpulkan dahulu di pos ini sebelum kemudian disetor ke Pos Kasir. Terakhir Pos Belanja adalah pos yang berhubungan dengan pengeluaran usaha. Baik itu untuk belanja bahan baku, operasional, maupun gaji karyawan.

Awal pencatatan dimulai dari Pos Kasir dan saldo berasal dari modal yang disetor oleh pemilik usaha ataupun yang berasal dari saldo bulan sebelumnya (dicatat sebagai uang masuk). Berikutnya, Pos Kasir menyerahkan uang ke Pos Belanja untuk belanja dan proses produksi.

\subsection{Permasalahan yang dihadapi UMKM di Indonesia}

Sektor usaha kecil menengah (UKM) memegang peranan penting dalam perekonomian negara. Sektor UKM memiliki pasar yang luas dan mampu menyerap 
banyak tenaga kerja. Di samping besarnya peluang, ada beberapa tantangan yang harus diketahui oleh pelaku UKM. Presiden Director PT Bahana Artha Ventura Andi dalam Bisnis (2014) mengatakan ada beberapa kendala yang menghadang pelaku UKM untuk mengembangkan bisnis, yaitu permodalan, administrasi, dan teknologi Kendala utama yang dihadapi UKM adalah modal. Karena masih berstatus bisnis mikro dan kecil, terkadang mereka tak dilirik lembaga perbankan. Di sinilah perusahaan modal ventura bergerak (Bisnis.com, 2014).

Selain modal, Andi (2014) menuturkan hambatan lain yang sering menjadi kendala para UKM adalah manajemen administrasi."Pelaku UKM banyak yang belum mengerti disiplin administrasi. Selain tak tahu cara membuat laporan keuangan, mereka malah mencampuradukkan antara pengeluaran pribadi dan perusahaan," imbuhnya. Masalah terakhir yang dihadapi oleh pelaku UKM adalah pemanfaatan teknologi. Menurutnya, teknologi dan penelitian biasanya dilakukan oleh kalangan perguruan tinggi (Bisnis.com, 2014).

\section{Metodologi Penelitian}

Penelitian merupakan metode deskriptif kualitatif, dan survey yang dilakukan terhadap industri rumah tangga (home industry) rakik di Kecamatan Pauh, Kota Padang. Langkah-langkah penelitian ini adalah (1). survey terhadap pelaku industri rumah rangga rakik. Tim peneliti mendatangi tempat industri mereka masing-masing, melakukan pengamatan terhadap kegiatan industri keseharian yang dilakukan. (2). In-depth interview, dimana tim peneliti melakukan wawancara mendalam dengan beberapa pertanyaan terstruktur.

Pertanyaan-pertanyaan dimulai seputar latar belakang didirikannya industri rumah tangga yang bersangkutan, dan dilanjutkan dengan pertanyaan-pertanyaan inti secara bertahap tentang bahan baku, tenaga kerja, hari produksi, dan pengelolaan keuangan (seperti sumber dana, dan cara menggunakan dana), serta hambatan-hambatan yang ditemui selama menjalankan industri. Hasil wawancara kemudian ditranskrip, Ialu didiskusikan tim peneliti, untuk dinarasikan dalam pembahasan masalah.

\section{PEMBAHASAN MASALAH}

\subsection{Gambaran Umum dan Permasalahan Entitas}

\subsubsection{Industri Rumah Tangga - Rakik Julidar}

Industri Rumah Tangga Rakik Julidar berlokasi Kelurahan Kapalo Koto, merupakan salah satu bentuk usaha dengan memberdayakan perempuan. Usaha rakik ini didirikan oleh Ibu Julidar sejak 20 tahun yang lalu. Ibu Julidar memproduksi 2 jenis rakik yaitu Rakik Kacang dan Rakik Maco. Awal berdiri, usaha ini murni dikelola sendiri oleh Ibu Julidar dan dibantu oleh anaknya. Usaha ini terus berkembang dan permintaan rakik juga terus meningkat.

Aktivitas produksi rakik dilakukan tiap hari dari jam 08.00 WIB sampai 16.00 WIB. Produksi per bulan mencapai 120 (seratus dua puluh) gantang tepung beras dan tepung tapioka yang dibagi atas 60 (sepuluh) gantang untuk rakik kacang, dan 60 (sepuluh) gantang untuk rakik maco. Dari hasil pengolahan setiap 20-nya gantang biasanya menghasilkan 80-100 bungkus rakik maco dan rakik kacang, yang mana setiap bungkus berisi 25 keping rakik.

Untuk membantu kelancaran produksi pemilik memberdayakan ibu-ibu yang tinggal sebelah rumahnya sebanyak lima orang untuk produksi rakik. Pembagian tugas adalah pemilik bertugas mengaduk adonan, empat orang bertugas pada penggorengan, dan satu orang bertugas pada pengemasan produk. Upah tenaga kerja diberikan per hari, sehingga pemilik memudahkan dalam menghitung biaya tenaga kerja. Adapun permasalahan lain yang dihadapi oleh pemilik entitas adalah :

\section{a). Aspek Teknologi Produksi.}

Peralatan penunjang untuk membuat rakik masih sangat tradisional yaitu menggunakan 
tungku api dengan kuali besar. Hal ini mengakibatkan lamanya pengerjaan rakik, meskipun sudah dibantu oleh empat orang tenaga kerja. Hal ini disebabkan karena pemilik tidak memiliki cukup modal untuk membeli tambahan peralatan untuk membuat rakik.

\section{b). Aspek Pengemasan}

Pengemasan rakik ini masih menggunakan plastik bening tipis serbaguna. Dari survey awal dapat dilihat bahwa plastik mudah sobek, dan plastik kemudian ditutup dengan cara diikat dengan gelang karet. Dengan kondisi kemasan rakik seperti ini, mengakibatkan seringnya kemasan jadi robek, dan mengakibatkan rakik jadi rusak atau lembek, dan berakibat kerugian bagi pemilik.

Pemilik menjalani kondisi tersebut sampai saat ini disebabkan kekurangan modal. Meskipun kekurangan modal, pemilik tidak berani melakukan pinjaman kepada bank. Ada beberapa alasan yang dikemukakan diantaranya suku bunga kredit perbankan masih tinggi, pemilik kurang memahami tentang perbankan ataupun lembaga non bank, rumitnya proses peminjaman dana, serta beratnya persyaratan yang diajukan pihak bank kepada pengusaha mikro untuk perolehan pinjaman.

\section{c). Aspek Administrasi Keuangan.}

Sebagaimana halnya pelaku usaha mikro lainnya, pemilik juga tidak pernah melakukan pencatatan atas pembelian bahan-bahan keperluan pembuatan rakik, pembayaran upah, ataupun penerimaan hasil penjualan. Sehingga pemilik tidak dapat menghitung secara tepat dan benar harga pokok rakik ini. Pemilik merasa omset mereka sudah cukup besar, namun keuntungan tetap saja tak tersisa di kas usaha. Ini disebabkan pemilik belum bisa mengatur keuangan dengan baik. Alasannya, karena tidak mengerti dengan cara admisitrasi dan tidak memiliki waktu untuk mencatat semua kegiatan produksi rakik ini.

\subsubsection{Industri Rumah Tangga - Rakik Fatmawati}

Industri Rumah Tangga Rakik Fatmawati berlokasi di Kelurahan Kapalo Koto, juga merupakan salah satu bentuk usaha dengan memberdayakan perempuan. Usaha rakik ini didirikan oleh Ibu Fatmawati juga sejak 20 tahun yang lalu. Sama hanya dengan lbu Julidar, Ibu Fatmawati memproduksi 2 jenis rakik yaitu Rakik Kacang dan Rakik Maco.

Permasalahan yang dihadapi oleh pemilik adalah :

\section{a). Aspek Teknologi Produksi.}

Meskipun sudah lama berdiri, cara penggorengan rakik masih menggunakan 2 (dua) tungku dan kuali penggorengan besar, sehingga proses pembuatan rakik menjadi lama meskipun sudah dibantu oleh dua orang tenaga kerja. Hal ini disebabkan karena pemilik tidak memiliki modal lebih untuk membeli tambahan peralatan untuk membuat rakik. Sampai saat ini untuk membantu kelancaran produksinya lbu Fatmawati memberdayakan anak-anaknya.

\section{b). Aspek Pengemasan}

Dalam hal pengemasan, pemilik juga menggunakan plastik bening tipis serbaguna dan gelang karet untuk pengikatnya. Kondisi kemasan rakik seperti ini, sering mengakibatkan kemasan jadi robek, dan berdampak rakik jadi rusak atau lembek. Hal ini berakibat kerugian bagi pengusaha kecil seperti Ibu Fatmawati. Kondisi ini dijalani oleh Ibu Fatmawati sampai saat ini. Faktor penyebabnya adalah kekurangan modal bagi pengembangan usaha.

\section{c). Aspek Administrasi Keuangan.}

Selama ini, pemilik juga tidak pernah melakukan pencatatan atas pembelian bahan-bahan keperluan pembuatan rakik, pembayaran upah, ataupun penerimaan hasil penjualan. Sehingga pemilik tidak dapat menghitung secara tepat dan benar harga pokok rakik ini. Sudah menjadi rahasia umum masalah keuangan kerap kali menjadi masalah besar dan sudah menjadi masalah umum Usaha Kecil Menengah (UKM).

Pemilik hanya dapat mentaksir biaya produksi dan hasil produksi dengan bahan 
yang dipakai. Hal ini disebabkan pemilik belum melakukan tertib administrasi untuk mencatat bahan baku yang dibeli, dan yang dipakai untuk keperluan proses pembuatan rakik. Alasannya, karena tidak mengerti dengan cara admisitrasi dan tidak memiliki waktu untuk mencatat semua kegiatan produksi rakik ini.

\subsection{Pemecahan Masalah}

\section{1). Teknologi Produksi.}

Setelah beberapa kali survey lapangan dan wawancara dengan kedua pemilik usaha rakik, dapat disimpulkan bahwa untuk berproduksi kedua usaha ini masih memakai teknologi yang cukup tradisional. Malah ada yang masih menggunakan kayu bakar sebagai bahan bakar. Akibatnya, pemilik dan karyawan memerlukan waktu yang cukup lama untuk memproduksi rakik. Adanya keengganan dari pemilik untuk beralih ke bahan bakar gas, agar lebih memudahkan dan hemat dari segi biaya dan waktu.

Dalam hal ini kedua pemilik mempunyai permasalahan kebutuhan peralatan produksi yang berbeda. Seperti halnya Usaha Rakik Julidar, pemilik usaha tetap memakai kayu bakar sebagai bahan bakarnya, karena pemilik beranggapan bahwa memakai kayu bakar masih relatif lebih mudah dan murah. Kedua pemilik juga memerlukan kuali besi besar untuk mengganti kuali lama yang sudah kurang layak digunakan dalam proses produksinya. Pemilik kesulitan dalam memperoleh pinjaman modal kerja, karena tidak memiliki akses ke pihak lembaga keuangan.

\section{Aspek Pengemasan.}

Pengemasan yang dilakukan selama ini oleh kedua entitas adalah masih memakai plastik tipis, dan merk yang seadanya. Sehingga tampilan menjadi kurang menarik, terlihat kusam, rakik mudah pecah, dan rusak. Hal ini mengakibatkan kerugian bagi entitas akibat produk rakik tidak terjual. Untuk membuat produk menjadi lebih menarik sebaiknya pemilik melakukan pemutakhiran pengemasan dengan yaitu dengan menggunakan peralatan pengemasan yang modern yaitu Mesin Hand Sealer. Disamping itu juga ditunjang oleh penggunaan plastik kemasan yang lebih tebal, sehingga produk lebih tahan lama dan lebih menarik. Sedangkan untuk tanda pengenal produk, pemilik sebaiknya memberi label. Tujuannya adalah pemberian label ini adalah untuk memberikan identitas yang lebih menarik, dan mudah diingat oleh konsumen tentang produk.

\section{Aspek Administrasi Keuangan.}

Dari hasil wawancara lanjutan diketahui bahwa kedua entitas mengalami kesulitan dalam menghitung harga pokok ataupun laba usaha rakik secara benar. Kedua entitas bahkan merasa mengalami kerugian, dan tidak mendapatkan kembali modal kerjanya. Faktor penyebabnya adalah bahan-bahan untuk membuat rakik cenderung mengalami kenaikan harga. Maka ada pemilik sebaiknya diberi pelatihan cara membuat pembukuan sederhana dan penyusunan laporan keuangan untuk industri rumah tangga yang paling sederhana untuk usaha mikro.

Tahapan untuk aktivitas ini adalah dimulai dengan pembekalan pengetahuan secara manual dan sederhana tentang Harga Pokok Produksi Rakik, membuat Buku Kas, Buku Belanja Bahan, Kartu Persediaan Bahan Rakik, Menghitung Harga Pokok Penjualan, dan Laporan Laba-Rugi, serta Laporan Perubahan Ekuitas/Modal.

Tahapan ini ditujukan agar pemilik memiliki keahlian dan dapat menghitung sendiri keuntungan usahanya. Disamping itu laporan keuangan ini nantinya dapat digunakan pemilik usaha mikro ini untuk pengusulan pinjaman kepada pihak ketiga, baik lembaga keuangan bank ataupun lembaga keuangan non bank.

Disamping itu pemilik juga sebaiknya juga dibekali dengan pengetahuan manajemen keuangan sederhana untuk usaha mikro. Tujuannya adalah agar pemilik dapat membuat menngelola keuangan dengan baik. Karena selama ini, pemilik usaha merasa omset dan penjualan meningkat, namun kas yang mereka terima tidak seperti yang mereka harapkan.

\section{KESIMPULAN DAN SARAN}




\subsection{Kesimpulan}

Sumatera Barat terkenal kaya akan kulinernya, baik berupa masakan ataupun kue-kue tradisional. Salah satu kue tradisional tersebut adalah Rempeyek atau dikenal dengan Rakik. Umumnya usaha rakik ini berbentuk home industry. Penelitian ini merupakan survey atas dua industri rumah tangga rakik di Kecamatan Pauh Kota Padang yang sudah berdiri selama 20 tahun. Berbagai permasalahan dihadapi oleh kedua industri rumah tangga ini diantaranya adalah aktifitas yang masih bersifat tradisional. Dalam hal ini terdapat keengganan dari pelaku bisnis untuk beralih ke proses produksi yang lebih modern.

Disamping itu pemilik juga belum mengelola keuangan dengan baik, hal ini terlihat dari mengalami kesulitan dalam menghitung harga pokok ataupun laba usaha rakik secara benar. Kedua entitas bahkan merasa mengalami kerugian, dan tidak mendapatkan kembali modal kerjanya. Pemilik kedua entitas diberi pelatihan cara membuat pembukuan sederhana dan penyusunan laporan keuangan untuk industri rumah tangga yang paling sederhana untuk usaha mikro. Tahapan untuk aktivitas ini adalah dimulai dengan pembekalan pengetahuan secara manual dan sederhana tentang Harga Pokok Produksi Rakik , membuat Buku Kas, Buku Belanja Bahan, Kartu Persediaan Bahan Rakik, Menghitung Harga Pokok Penjualan, dan Laporan Laba-Rugi, serta Laporan Perubahan Ekuitas/Modal.

Begitu juga hanya dengan pengemasan dan label yang dilakukan selama ini oleh kedua entitas adalah masih memakai plastik tipis, dan merk yang seadanya. Sehingga tampilan menjadi kurang menarik, terlihat kusam, rakik mudah pecah, dan rusak. Untuk itu dilakukan pemutakhiran pengemasan dengan yaitu dengan menggunakan peralatan pengemasan yang modern yaitu Mesin Hand Sealer, plastik kemasan yang lebih tebal, sehingga produk lebih tahan lama dan lebih menarik. Sedangkan untuk tanda pengenal produk, pemilik sebaiknya memberi label. Tujuannya adalah pemberian label ini adalah untuk memberikan identitas yang lebih menarik, dan mudah diingat oleh konsumen tentang produk.

\subsection{Saran}

Sebaiknya untuk peneliti selanjutnya menguji secara kuantitatif dan menganalisis lebih mendalam dengan memperluas sampel penelitian, dan menkaji tentang profil dan permasalahan industri rumah tangga untuk usaha rakik ini. Sehingga terpetakan secara umum permasalahan yang spesifik dari home industri rakik ini.

\section{DAFTAR PUSTAKA}

Barlian, Inge; Gomulia, Budiana, dan Manurung, Elvy Maria, 2012, Pengelolaan Keuangan Oleh Pengusaha Perempuan Pada Beberapa Bisnis Kreatif di Bandung (Studi Kasus PadaBisnis Kreatif : fesyen, kerajinan, dan film), Universitas Katolik Parahyangan, Bandung.

Bahan Pelatihan untuk Calon Wirausaha Buku 4, Modul 3, Manajemen Usaha Kecil, Direktorat Pembinaan Kursus Dan Kelembagaan, Direktorat Jenderal Pendidikan Non Formal Dan Informal, Kementerian Pendidikan Nasional, 2010, Jakarta

Fitriani, Feni Freycinetia, 2014, Ini 3 Kendala Utama Perkembangan UKM, Bisnis.com , didownload tanggal 10 Nopember 2015

Fajar, Aditya, 2013, Pembukuan Sederhana Usaha Kecil dan Rumahan, didownload tanggal 13 Nopember 2015.

Hartati, Sri, 2013, Manajemen Keuangan Untuk Usaha Mikro, Kecil Dan Menengah, http://www.apwi-pwu.com/wp-content 
/uploads/2013/01/Artikel-Sri-Hartati.p df

http://Yustinus-Mahu.Blogspot.Com/2012/04/ Peta-Permasalahan-Keuangan-Peng usaha.Html (Didownload Tanggal 05 April 2014)

http://Gilaekonomi.Blogspot.Com/2012/03/Tra ining-Pembukuan-Dan-Penyusunan. Html; Training Pembukuan Dan Penyusunan Laporan Keuangan Pada Usaha Kecil Dan Menengah, (2012), , Didownload Tanggal 23 April 2014.

http://Ramesiamesin.Com/Hand-Sealer/

http://Keuanganlsm.Com/Pengelolaan-Keuan gan-Bagi-Ukm/Pengelolaan;

Keuangan Bagi Ukm /; Senin 23 Desember 2013

http://tyningdiah.blogspot.co.id/2013/06/keua ngan-usaha-kecil.html, didownload tanggal 11 Nopember 2015

Pereira, Isaac, 2012, Proses Pembuatan Rempeyek Pada Industri Rumah Tangga Di Desa Tulungrejo Kecamatan Bumiaji Batu, Laporan Praktek Kerja Lapang, Program Studi Teknologi Industri Pertanian; Fakultas Pertanian; Universitas Tribhuwana Tunggadewi; Malang.

Pusat Peluang Usaha dan Jaringan Bisnis UMKM, Menangani Masalah Manajemen UKM; 2009.

Peraturan Direksi Lembaga Pengelola Dana Bergulir Koperasi dan Usaha Mikro, Kecil, dan Menengah Nomor : 36/PER/LPDB/2010 tentang Petunjuk Teknis Pemberian pinjaman/pembiayaan kepada koperasi

Rahmawati, Diana, 2008, Pengetahuan Akuntansi untuk Perusahaan Kecil
Pada Usaha Kecil/Home Industry Tepung Aren dan Mie Sohun Di Desa Dalemen, Kec. Tulung, Kab. Klaten.

Susanti, Dewi, 2014, Profil Industri Rumah Tangga Rakik Lokan Sebagai Pengembangan Ekonomi Keluarga di Kampung Tanjung Medan, KEcamatan Pancung Soal, Kabupaten Pesisisr Selatan, Program Studi Geografi, Sekolah Tinggi Keguruan dan IImu Pendidikan (STKIP) PGRI Padang, Sumatera Barat.

Tasrifin.dosen.narotama.ac.id/.../Modul-KUM KM-4-Manajemen-Usaha-K..

Website Badan Pusat Statistik (BPS).

Website Kementerian Koperasi, dan UMKM.

Wartadiani, Maria Ditya ; Pratiwi, Atika Cahya ; dan Putra, Brahmantio Taufan Anata; (2012); Perbaikan Desain Alat Peyek Tumpuk Untuk Peningkatan Keseragaman Mutu Produk; Sma Negeri 6 Yogyakarta, "The Research School Of Jogja", Jalan Cornelis Simanjuntak No.2 Yogyakarta. 